\title{
Two Hyaluronan-binding Domains in the Receptor RHAMM
}

\author{
RHAMM(HAレセプター)の 2 ケ所のヒアルロナン(HA)結合ドメインの同定
}

Yang, B., Zang, L., and Turley, E.A. (1993) J. Biol. Chem. 268, 8617-8623

Key Words: hyaluronan-binding, receptor RHAMM

Hyaluronan (Hyaluronic acid, HA) is the largest unsulfated glycosaminoglycan of the extracellular matrices in the mammalian connective tissues. HA is bound to the cell surface of several types of cells in culture. Binding is at least in some cases, mediated by specific receptors. Such receptors have been found on liver cells, on transformed fibroblasts and chondrocytes. A number of cell-associated and extracellular HA-binding proteins have been identified. These include the motility receptor (RHAMM), CD-44, aggrecan, link proteins, and vercican. Such specific receptors-mediated bindings to HA are important in the morphogenesis of the tissue, wound repair, tumor invasion, immune recognition, regulation of cell locomotion and cytodifferentiation. Although both HA receptors and extracellular binding proteins have been well studied, HA binding motifs of these proteins have not identified yet. RHAMM binds to HA with high specificity and high affinity $\left(\mathrm{Kd} 10^{-8} \mathrm{M}\right)$ : The amino acid sequence of the receptor as revealed by the corresponding nucleotide sequence of cDNA of RHAMM was found to bear no homology with known other HA-binding proteins. Moreover, the sequence of RHAMM does not contain typical tandem repeat loops in the sequence as found in other HA-binding proteins. Therefore, RHAMM represents a novel kind of a HA-binding protein. The present report identifies two discrete HA-binding domains in the HA-receptor RHAMM (Receptor for HA-Mediated Motility) that mediates locomotion of $\mathrm{H}$-ras transformed fibroblasts.

Previously, the present investigators have cloned a novel HA receptor (RHAMM) that is expressed in high levels in mutant $\mathrm{H}$-ras transformed cells, promotes locomotion and alters contact behavior (Hardwick et al. J. Cell Biol., 117, 1343$1350,1992)$. They have also identified the carboxyl terminus of a HA-binding pro tein as defective in mutants of H-ras transformed cells. Therefore, H-ras transformed fibroblast cells are appropriate model system to identify the motifs on the HAbinding proteins.

Construction of RHAMM cDNA: The RHAMM cDNA reading frame was amplified with PCR technique by using oligonucleotides as primers, one complimentary to the translation initiation region creating a BamHI site linked to number one nucleotide, the other complimentary to the region 200 bases after the translational stop cordon creating an EcoRI site linked to nucleotide 1706. The full-length cDNA inserted into Blue
ヒアルロナン(旧名ヒアルロン酸、一般にHAと略称)は哺乳 動物の結合組織の細胞外マトリックスを形成するグリコサミノ グリカンの中では最大のものであり硫酸化されていない。HAは 培養下の様々な細胞の表面に結合する。この結合はある場合に は特異的なレセプターを介して起こる。このようなレセプター は肝細胞、トランスホームした線維芽細胞および軟骨細胞で見 付かっている。HAレセプターとして細胞表面に存在するレセプ ターや細胞外で働らくHA結合タンパク質があり、細胞の運動性 レセプター(RHAMM)、CD44、アグレカン、リンクタンパク 質、ヴァーシカンなどが知られている。このような特異的レセ プターを介するHAへの結合は、組織の形態形成、傷の治癒、腫 瘍の浸潤、免疫における認識、細胞の運動性の制御や細胞分化 において重要である。HAレセプターと細胞外のHA結合タンパ ク質とはよく研究されているが、これらにおけるHA結合モ ティーフはまだ同定されていなかった。RHAMMはHAと非常に 特異的にかつKdが $10^{-8} \mathrm{M}$ という高親和性で結合する。RHAMM のcDNAのヌクレオチド配列から推定されるアミノ酸配列には 他の既知のHA結合タンパク質と全くホモロジーはない。更に RHAMMの配列中には、他のHA結合タンパク質中に見出される ような典型的なタンデムリピートのループは見付からない。 従って、RHAMMは新らしい種類のHA結合タンパク質である。 ここに紹介する本論文では、H-rasによりトランスホームした線 維芽細胞の運動を制御するHAレセプターであるRHAMM中の2 つの明確なHA結合ドメインを同定している。

この論文の著者達は既にH-rasでトランスホームした変異細 胞中で高度に発現し、運動性を促進し、そして細胞増殖の結果 として通常誘導される接触阻害時の行動を変えてしまう新らし いHAレセプター(RHAMM)のクローニングに成功している [Hardwick et al. (1992) J. Cell Biol. 117, 1343-1350]。彼等はH-ras でトランスホームした細胞ではHA結合タンパク質がC末端で欠 失していることを見ているので、この変異株はHA結合タンパク 質のモティーフを同定するよいモデル系である。

RHAMM cDNAの構成: RHAMM cDNAの翻訳開始部分を、1 つは翻訳開始部位に相補的であり1番目のヌクレオチドに結合す るBamHIサイトを作るオリゴヌクレオチド、もう1つは翻訳停止 コドンの200塩基あとの領域に相補的であり且1706番目のヌク レオチドに結合するEcoRIサイトを作るオリゴヌクレオチドの2 つのプライマーを用いてPCR法により増幅した。Blue 
Script (Staratagene) was used as a template. After the appropriate enzyme digestions, the EcoRI-BamHI DNA fragment was ligated to an EcoRI and BamHI opened pGEX-2T plasmid (Pharmacia). The ligated mixture was transformed into competent $E$. coli $\mathrm{HB} 101$ cells and the conventional procedures were used to obtain positive colonies. The recovered RHAMM cDNA insert was confirmed by restriction enzyme digestions and agarose gel electrophoresis.

Truncation of RHAMM cDNA: The recombinant plasmid obtained as described above was digested with the following restriction endonucleases, AatII, EGII $\pm E c o$ RI, NcoI $+E c o$ RI and $S a c I-E c o$ RI. Digests were blunt-ended with Klenow fragment. The plasmid containing truncated RHAMM cDNA was recovered, self-ligated and then transformed into HB101 cells as described above. Positive clones were selected by hybridization with RHAMM cDNA and confirmed to contain truncated RHAMM cDNA by restriction enzyme digestions and gel electrophoresis.

Preparation of a fusion protein: Colonies of pGEX-2T plasmids containing cDNA were grown in a suitable medium containing isopropyl-thio-D-galactoside to induce biosynthesis of a fusion protein. The cells were harvested, disrupted by sonication and centrifuged. The supernatant that contained Glutathione-S-transferase-RHAMM fusion protein was recovered and used for Western blot assays.

Construction of recombinant RHAMM containing oligonucleotides encoding HA-binding peptides: PCR was used to incorporate truncated oligonucleotides of $\mathrm{HA}$ binding region peptides (401-411 and 423-432) respectively into cDNA encoding the $\mathrm{N}$ terminus of the RHAMM that was prepared as a $0.71 \mathrm{~kb}$ fragment. The fusion protein products of this fragment did not have the ability to bind HA. Two PCR primers were used (5' specific nucleotide sequence). Recombinant cDNA was obtained by using PCR primers. PCR products were digested with EcoRI and BamHI and purified by agarose gel electrophoresis. Recombinant cDNA was then inserted into pGEX-2T and transformed into HB101 cells. The correct insertion was confirmed by restriction endonucleases digestiod of the selected clones followed by agarose gel electrophoresis.

Results can be summarized as follows:

i) Expression of RHAMM cDNA: The fusion protein has a molecular weight of $87 \mathrm{kD}$. On Western blot analysis, the protein reacted with i) polyclonal antibodies to a peptide encoded in RHAMM (128-145) and ii) to monoclonal antibodies specific for RHAMM, iii) biotin-labeled HA.

ii) Determination of HA-binding region of RHAMM: To determine the region, the ability of the variety of truncated fusion protein products to bind HA was evaluated in a transblot assay. The complete fusion protein bound to HA as did the SacI truncation but the fusion products expressed from the $\mathrm{NcoI}$ and AatII truncated RHAMM cDNA did not react. These results
Script(Stratagene社)中に㨂入した完全長のcDNAを鋳型として用 いた。適当な酵素分解のあとEcoRI-BamHIによるDNA断片を EcoRIとBamHIで開いたpGEX-2Tプラスミッド(Pharmacia社)中 にライゲートした。ライゲートした混合物でE. coli HB101細胞 をトランスホームし通常の方法で陽性クローンを単離した。回 収されたRHAMM cDNAインサートは制限酵素分解とアガロー スゲル電気泳動により確認された。

不完全RHAMM CDNAの構成: 上記のようにして得られた組換 えプラスミッドを、AatII、EGII \pm EcoRI、Ncol + EcoRI、SacI + EcoRIで消化し、Klenow断片により端を揃えた。不完全な RHAMM cDNAを含むプラスミッドを回収し、自己ライゲート し、上記のような方法でHB101細胞にトランスホームした。 RHAMM cDNAとハイブリダイズする陽性クローンを拾い、制 限酵素分解とゲル電気泳動により一部を欠失したRHAMM cDNAを含んでいることを確認した。

融合タンパクの調製: cDNAを含むpGEX-2Tプラスミッドのコ

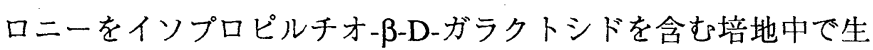
育し、融合タンパクの合成を誘導した。細胞を回収し、超音波 処理で破壊し遠心した。グルタチオン-S-転移酵素-RHAMM融 合タンパクを含む上清を回収しウェスタンブロットに用いた。 HA一結合ペプチドをコードするオリゴヌクレオチドを含む リコンビナントRHAMMの構成:一部を欠失したHA結合ペプ チドのオリゴヌクレオチド(401-411と423-432)をそれぞれ RHAMMのN末端をコードするcDNA(0.71 kb断片)に入れるため PCRを行なった。この断片の融合タンパクはHAと結合できな かった。PCRプライマーとして2個用いて、リコンビナント cDNAを調製した。PCRの産物をEcoRIとBamHIで消化しアガ ロース電気泳動で精製した。リコンビナントcDNAをpGEX-2T 中に挿入しHB101細胞をトランスホームした。正しく挿入され たかどうかはクローンを選んで制限酵素分解とアガロースゲル 電気泳動をすることで確認された。

結果は次のように要約できる

1) RHAMM CDNAの発現: 融合タンパクの分子量は $87 \mathrm{kD} ゙$ あ り、ウェスタンブロット解析では、i)RHAMM(128-145)でコー ドされるペプチドに対するポリクローナル抗体、ii)RHAMMに 特異的なモノクローナル抗体、iii)ビオチン標識HAと反応し た。

II) RHAMMのHA結合領域の決定: 結合領域を決めるため に、様々な不完全融合タンパクのHA結合能をトランスブロット 検定法で調べた。完全融合タンパクとSacIによる不完全融合夕 ンパクはHAに結合したが、NcoIとAatIIによる不完全RHAMM cDNAから発現された融合タンパクは結合しなかった。このこ 
implied that the $\mathrm{NcoI}-\mathrm{SacI}$ fragment containing 95 amino acid sequence near the carboxyl terminus was essential for binding to HA.

iii) Identification of two HA-binding motifs: Two sequences encoded in the NcoI-SacI fragment (nucleotides 1201-1233 and ç1267-1296) called as motifs were tested for binding to HA in çthree different ways. In the first approach, the region was deleted and the resulting expressed truncated fusion protein was tested for its ability to bind to HA.

In the second approach, peptides were synthesized that mimic the two regions containing positive charge clusters (as these clusters have been shown to be involved in the binding) for their ability to bind HA-Sepharose and to complete with RHAMM for their binding to biotin-labeled HA in a transblot assay. In the third approach, oligonucleotides encoding the putative binding domains were genetically engineered, using PCR to the $0.71 \mathrm{~kb}$ cDNA fragment (non-HA binding). The altered fusion protein products were then tested for their abilities to bind HA. Results showed that peptide (401-411) and peptide (423-432) blocked the binding of biotin-labeled HA to the expressed fusion protein. To directly demonstrate the ability of the two peptides to bind HA, peptides were chromatographed on HA-Sepharose column. Several controls were included in the setup of the experiment to eliminate the artifacts of nonspecific binding. Results showed that only peptide (401-411) and peptide (423-432) efficiently bind to HA. DNA sequences encoding peptides were linked to the $B g$ III truncated RHAMM cDNA which encodes the $27.5 \mathrm{kD}$ polypeptide of the amino terminus of RHAMM. These recombinant sequences were then expressed as recombinant fusion proteins. The HA binding activity was then tested as described above. The truncated RHAMM fusion protein containing these peptides were found to bind HA efficiently.

The major important findings of this report are that a critical interaction of HA with RHAMM receptor takes place to a region of 35 amino acids (400-434) near the carboxy terminus of this protein. This region contains clusters of basic amino acids which are of very much importance in the binding process. The binding of heparin, a glycosaminoglycan related to HA, to heparin-binding protein relies upon clusters of positive charges. Proteins that bind heparin often do not share amino acid sequences homology in their heparin-binding regions. The basic amino acids in these clusters have to be arranged in a specific way in an orderly fusion. Thus there are similarities between binding phenomenon of HA and heparin. The ionic interactions between two molecules are important in such bindings. Most of the HA-binding proteins (not receptors) contain homologous tandem repeat loops that occur near amino terminus e.g., aggrecan, CD 44, link proteins, and vercican. Among these proteins, there is no single region of peptides which is common to all. RHAMM receptor does not contain such tan-
とはC末端に近く、95アミノ酸残基を含むことになるNcoI-SacI 断片がHA結合に重要であることを示している。

III) 2つの結合モティーフの同定: NcoI-SacI断片(ヌクレオテド 1201-1233および1267-1296)でコードされる2つのアミノ酸配列 はモティーフと呼ばれているが、そのHA結合能を3通りの方法 で調べた。第1にはこの部分を欠失させ、その結果の不完全融合 タンパク質のHA結合能の有無が調べられた。

第2には、陽性に荷電するクラスターが結合に効いている

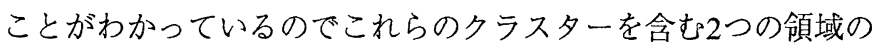
アミノ酸配列を変えたペプチドを合成し、HAーセファロースへ の結合能と、トランスブロット検出法でビオチン標識HAとの結 合がRHAMMと競合できるかが調べられた。第3番目には、推定 上の結合ドメインをコードするオリゴヌクレオチドを遺伝子操 作で0.71 kb cDNA断片(HAに非結合性)に対するPCR法により改 変した。このようにして改変した融合タンパクのHA結合能が調 ベられた。ぺプチド(401-411)とぺプチド(423-432)はビオチン標 識HAと融合タンパクとの結合を阻害した。この2個のペプチド がHAと直接結合することを証明するために、これらのペプチド をHA-セファロースカラムクロマトグラフィーにかけた。勿 論、非特異的結合のアーティファクトを除くためにコントロー ル実験が組まれている。結果は、ペプチド(401-411)とペプチド (423-432)のみがHA結合能を示した。これらのペプチドをコー ドするDNA配列を、RHAMMのN末端の27.5 kDaポリペプチド をコードする部分だけにBg1IIで切断した不完全cDNAに結合し た。このリコンビナントの配列をリコンビナントの融合タンパ クとして発現させ、上記のようにHA結合能を調べると、これら のペプチドを含む不完全RHAMM融合タンパクはHAと明らかに 結合できるようになった。

この論文の重要な発見は、RHAMMレセプターとHAとの 相互作用はこのRHAMMのC末端に近い35アミノ酸残基(400434)の領域で起こるということである。この領域は結合過程に 大変重要な塩基性アミノ酸のクラスターを含んでいる。HAに似 たグリコサミノグリカンの1つであるへパリンとへパリン結合夕 ンパク質との結合には、陽性に荷電したクラスターの存在汃必 須である。ヘパリンと結合できる他の多くのタンパク質はヘパ リンと結合する領域中であまりアミノ酸配列のホモロジーがな い。この領域のクラスター中の塩基性アミノ酸は秩序のあるあ る配列をとるよう空間的に折りたたまれなくてはならない。こ のようにして、HAとへパリンの結合様式には相似性がある。二 者の分子間のイオン性相互作用はこのような結合において大変 重要である。HAレセプターを除く多くのHA結合性タンパク は、アグレシン、CD44、リンクタンパク質やヴァーシカンで見 られるように、アミノ末端近くに相同のタンデムリピートを 持っている。これらのタンパクには、すべてに共通にみられる ようなぺプチド領域はひとつもない。RHAMMレセプターには タンデムリピートのループは存在しない。RHAMMレセプター 
dem-repeat loops. The amino acid sequences in the RHAMM receptor are not homologous to other HA-binding proteins.

The H-ras transformed fibroblasts and RHAMM receptor protein offer a unique model system to study the functions of receptors. This is the first report demonstrating the importance of specific motifs containing clusters of basic amino acids in the protein in their abilities to bind HA. The physiological significance of these findings remain to be elucidated.

\section{Reported by Damle, S.P.}

The Rockefeller University, New York, U.S.A.
中のアミノ酸配列は他のどのHA結合タンパクとも相同性がな w。

H-rasによりトランスホームした線維芽細胞とRHAMMレセ プターは、レセプター機能を研究する好適のモデルとなる。こ の論文は、塩基性アミノ酸のクラスターを含む特異的なモ ティーフがHAに結合するためには重要であることを示した最初 の論文である。この発見の生理的な意義の解明にはまたここの先 の研究が必要である。

ロックフェラー大学

S.P. ダムレ

東京工業大学 ·生命理工学部 ·生体分子工学 - 糖鎖生命科学 山形 達也訳 